[Agr. Biol. Chem., Vol. 30, No. 3, p. 274 277, 1966]

\title{
The Influence of Low Protein Diet on the Composition of Rat Liver Cell Fractions
}

\author{
By Naoko HARAda and Shigeaki Mogi ${ }^{*}$ \\ Chukyo Women's University, Ohbu, Chita-gun, Aichi-ken *Department of \\ Agricultural Chemistry, Nagoya University, Anjo, Aichi-ken \\ Received September 20, 1965
}

\begin{abstract}
Rats were divided into high protein diet and low protein diet fed groups. Their livers were removed, homogenized, and fractionated into nuclei, mitochondria, microsome and supernatant fraction.

Amount of total- and phospho-lipids in each fraction was measured, and simultaneously, total nitrogen was measured. Then, the ratio of total-and phospho-lipids to nitrogen was calculated. The influence of low protein diet on this calculated value was seen in the mitochondrial and supernatant fraction, but was not recognized in other fractions.

The relationship between this phenomenon and energy efficiency of diets was discussed.
\end{abstract}

Harada and Ashida pointed out that when rats were fed the low protein diets, the energy efficiency of diets with respects to body protein maintenance decreased in those rats. ${ }^{11}$ In order to maintain the same amount of body protein, the food intake in rats fed the lower protein diet must be greater than in those fed the higher protein diet. Thus, in rats fed the low protein diet, the enzyme system concerning the energy metabolism varies. The organization and composition of oxidation reduction enzyme system may also vary.

Recently, several workers have reported that the enzymes of oxidation reduction system operate in the form of lipoprotein, that is, in the form of protein conjugated with lipids. $^{2 \sim 5)}$ We have considered that in rats fed the low protein diet, the variation of oxidation reduction enzyme system would be reflected in the composition of lipoprotein.

1) N. Harada and K. Ashida, This Journal, 28, 56 (1964).

2) S. W. Edwards and E. G. Ball, J. Biol. Chem., 209, 619 (1954).

3) S. Fleischer and H. Klouwen, Biochem. Biophys, Res. Commun., 5, 378 (1961).

4) I. Sekuzu, P. Jurtshuk Jr. and D. E. Green, Biochem. Biophys. Res. Commun., 6, 71 (1961).

5) S. Fleischer, G. Brierley, H. Klouwen and D. B. Slautterback, J. Biol. Chem., 237, 3264 (1962).
In this experiment, we considered furthe that the variation of composition of lipoprotei would be reflected in the ratio of total- an phospho-lipids to protein.

Since different cell fractions have differer biochemical and physiological activity, an oxidation reduction enzymes locate themselve almost in mitochondria, we fractionated th rat liver cell into nuclei, mitochondria, micr some and supernatant, measured the ratio $c$ total- and phospho-lipids to protein, an examined the influence of low protein die on these values.

\section{EXPERIMENTAL}

\section{Animals and Diets}

Male rats of Donryu strain were used. They wer housed in individual cages in a temperature regulate room at about $22^{\circ} \mathrm{C}$.

As the test diets, high protein diet and low protei diet were used. As the high protein diet, 25\% casei diet, and as the low protein diet, $7 \%$ and $4 \%$ casei diets were used. Their composition is shown 1 Table I. Each diet contained 5\% corn oil, 5\% mineral mixture, ${ }^{6)} 0.25 \%$ vitamin mixture, ${ }^{6)} 0.15 \%$ choline chloride, and made up to $100 \%$ with potat

6) A. E. Harper, J. Nutrition, 68, 405 (1959). 
TABLe I. Composition of Diets

\begin{tabular}{|c|c|c|c|}
\hline \multirow[b]{2}{*}{ Ingredient } & \multicolumn{3}{|c|}{ Test diets } \\
\hline & $\begin{array}{l}4 \% \\
\text { casein }\end{array}$ & $\begin{array}{c}7 \% \\
\text { casein }\end{array}$ & $\begin{array}{c}25 \% \\
\text { casein }\end{array}$ \\
\hline & $\%$ & $\%$ & $\%$ \\
\hline Casein & 4 & 7 & 25 \\
\hline$\alpha$-Starch & 85.6 & 82.6 & 64.6 \\
\hline Corn oil & 5 & 5 & 5 \\
\hline Mineral mix. $\mathrm{B}$ & 5 & 5 & 5 \\
\hline Vitamin mix. & 0.25 & 0.25 & 0.25 \\
\hline Choline & 0.15 & 0.15 & 0.15 \\
\hline Total & 100 & 100 & 100 \\
\hline
\end{tabular}

$\alpha$-starch. But the concentration of vitamin mixture is about one third of that reported originally by Harper.6) Diets were supplemented further with 6000 I.U. of vitamin A and 600 I.U. of vitamin D per $1 \mathrm{~kg}$ of diets.

\section{Assay Procedure}

Lipids were all extracted by the method of Folch') using chloroform-methanol $(2: 1)$. In the extraction procedure, precaution was taken not to raise the temperature above $70^{\circ} \mathrm{C}$.

Lipid phosphorus was determined on aliquots of the extracted sample by determining total phosphorus by the method of Allen. ${ }^{8}$ ) Phospholipids were calculated by multiplying 25 to the value of phosphorus.

Nitrogen was determined by semimicro-Kjeldahl method on lipid extracted sample after digesting with sulfuric acid.

\section{Plan of Experiment}

Rats of initial body weight of about $150 \mathrm{~g}$ were used. They were divided into four groups, i.e., $25 \%$ ad libitum and restricted feeding groups, $7 \%$ and $4 \%$ ad libitum groups. Twenty-five per cent restricted group was given restricted amount of $25 \%$ casein diet in order that the body weight of this group may remain in the same level as that of $7 \%$ ad libitum group. Rats were all given test diets for about six months, and after that they were killed and livers were removed quickly and fractionated as described below.

\section{Liver Cell Fractionation}

Liver cell was fractionated essentially by the method of Schneider ${ }^{9,10)}$ using ice cold $0.25 \mathrm{M}$ sucrose solution.

$7)$ J. Folch, M. Lees and G.H. Sloane Stanley, $J$. Biol. Chem., 226, 497 (1957).

8) R.J.L. Allen, Biochem. J., 34, 858 (1940).

9) W.C. Schneider and G.H. Hogeboom, if. Biol. Chem. 183, 123 (1950).

10) W. W. Umbreit, R.H. Burris and J.F. Stauffer, "Manometric Techniques" 1957 , p. 188.
Liver was homogenized with about tenfold volumes of ice cold $0.25 \mathrm{M}$ sucrose solution using teflon homogenizer. Nuclei was separated by centrifuging the above homogenate for five minutes at $600 \times \mathrm{g}$, and mitochondria was separated by centrifuging the above supernatant for ten minutes at $10000 \times \mathrm{g}$. Microsome was separated by centrifuging the supernatant fraction devoid of mitochondria and nuclei for one hour at $100000 \times \mathrm{g}$.

The supernatant protein was precipitated with trichloroacetic acid as reported by Marinetti et al.,11) and the lipids of lipoprotein were extracted with solvent after neutralization of precipitated fraction with small volume of sodium hydroxide solution.

\section{RESULTS}

In Table II, final body weight and liver weight are shown. Body weight of rats fed the $7 \%$ casein diet ad libitum and that of rats fed the restricted amount of $25 \%$ casein diet remained almost the same.

Fig. 1 shows the ratio of total lipids to nitrogen. This value became larger in low protein fed groups in mitochondrial fraction, and the difference was not recognized in other fractions. The difference was significant between $25 \%$ ad libitum and $4 \%$ groups $(\mathrm{P}<$ 0.01 ), and between 25\% ad libitum and $7 \%$ groups $(\mathrm{P}<0.05)$. The effects of caloric restriction was seen only in supernatant fraction.

Fig. 2 indicates the ratio of phospholipids to nitrogen. This time, the difference was

\begin{tabular}{|c|c|c|c|}
\hline ABLE II. & $\begin{array}{l}\text { FINAL BODY } \\
\text { WEIGHT O }\end{array}$ & $\begin{array}{l}\text { WEIGHT A } \\
\text { RATS }\end{array}$ & ND LIVER \\
\hline \multirow{2}{*}{ Group } & $\begin{array}{c}\text { Final body } \\
\text { weight }\end{array}$ & $\begin{array}{c}\text { Final liver } \\
\text { weight }\end{array}$ & \multirow{2}{*}{$\begin{array}{l}\text { Number } \\
\text { of rats } \\
\text { per group }\end{array}$} \\
\hline & $\mathrm{g}$ & $\mathrm{g}$ & \\
\hline $\begin{array}{l}4 \% \text { casein } \\
\text { ad libitum }\end{array}$ & $135 \pm 191$ & $+.9 \pm 15$ & 4 \\
\hline $\begin{array}{l}7 \% \text { casein } \\
\text { ad libitum }\end{array}$ & $241 \pm 15$ & $7.1 \pm 0.4$ & 4 \\
\hline $\begin{array}{l}25 \% \text { casein } \\
\text { ad libitum }\end{array}$ & $375 \pm 32$ & $12.1 \pm 1.7$ & 4 \\
\hline $\begin{array}{l}25 \% \text { casein } \\
\text { restricted }\end{array}$ & $237 \pm 13$ & $6.8 \pm 0.2$ & 6 \\
\hline
\end{tabular}

1) Standard Deviation.

11) G.V. Marinetti, J. Erbland and E. Stotz, J. Biol. Chem., 233, 562 (1958). 


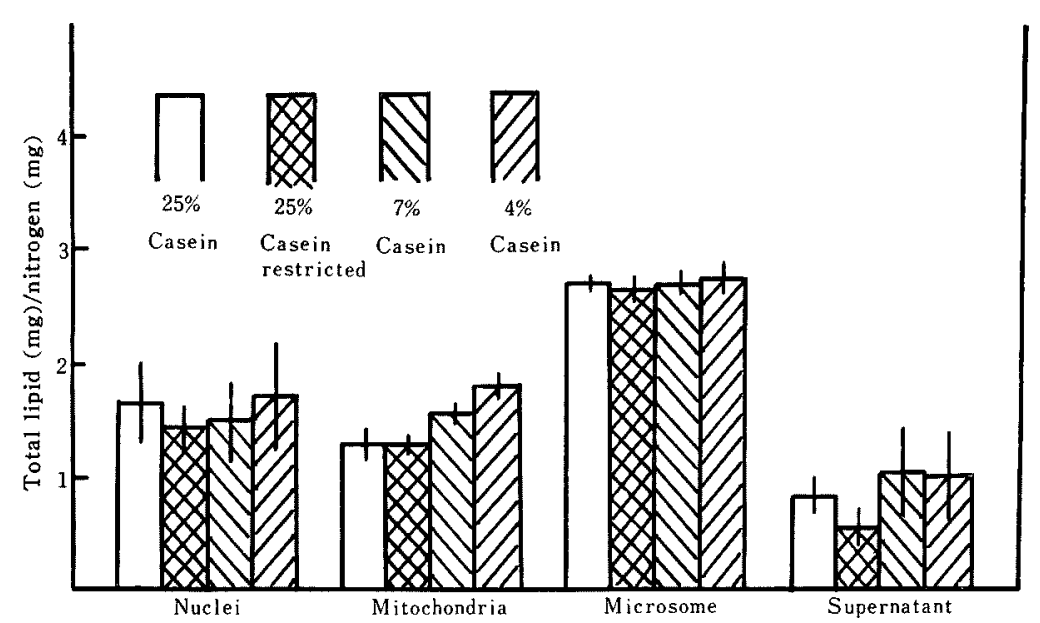

FIG. 1. Mean of Ratio of Total Lipids to Nitrogen of Rat Liver Cell Fractions. Vertical lines represent standard deviation.

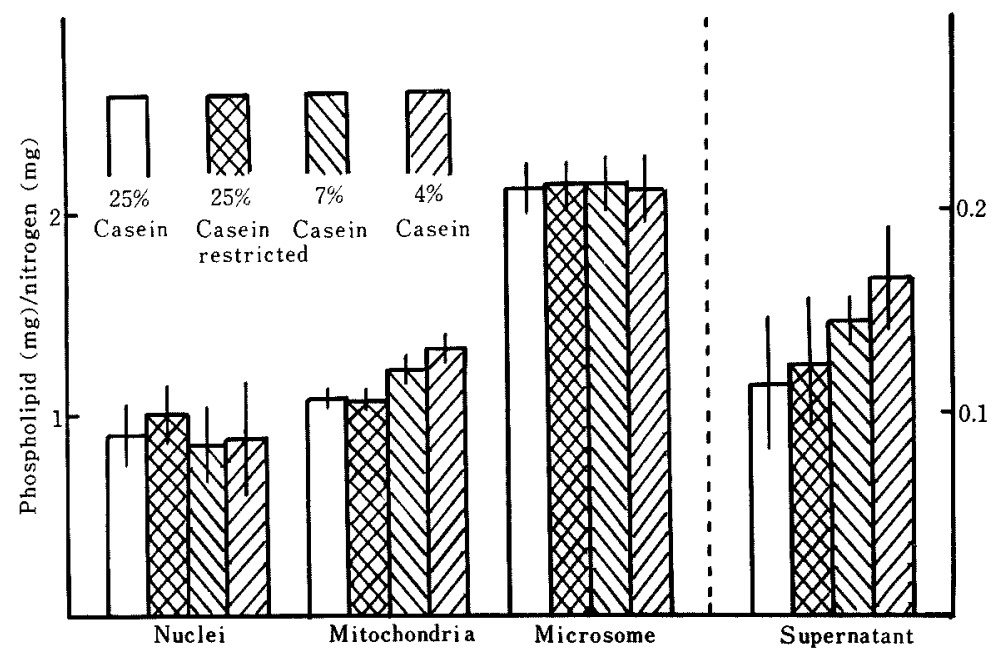

FIG. 2. Mean of Ratio of Phospholipids to Nitrogen of Rat Liver Cell Fractions. The scale is tenfold in supernatant fraction only.

recognized in mitochondrial and supernatant fractions. The difference in mitochondrial fraction was significant between $25 \%$ ad libitum and $4 \%$ groups $(\mathrm{P}<0.01)$ and between $25 \%$ ad libitum and $7 \%$ groups $(\mathrm{P}<0.05)$. The effect of caloric restriction was not seen at all.
From the above results, the influence of $10^{\prime}$ protein diet on mitochondrial fraction wi evident. The effect on supernatant fractio was seen in the ratio of phospholipids 1 nitrogen, though the difference was ni significant. 


\section{DISCUSSION}

In this experiment, as was expected, the low protein diet exerted an influence on mitochondrial fraction, and not on nuclei and microsomal fraction.

From this results, we consider it appropriate to assume that the nature and composition of lipoprotein of rat liver mitochondria vary according to the change in dietary protein level. At present, the nature and composition of mitochondrial lipids are under investigation.

The relationship between the nature of mitochondrial lipoprotein and the oxidation reduction enzyme activity might not be simple. When compared on the basis of the same body protein amount, food intake was greater in rats fed the low protein diet than in rats fed the high protein diet. ${ }^{1}$ The respiration must be greater in rats fed the low protein diet than in rats fed the high protein diet. In such a severe feeding condition as the low protein diet, to respire vigorously, mitochondrial oxidation reduction enzymes must operate fully under bad conditions. Therefore, in low protein fed animals, the mode of association of oxidation reduction enzymes varies in such a way as to make electron transfer go smoothly. We have considered the variation of organization and composition of lipoprotein of mitochondria in connection with this phenomenon.

In addition, the difference was recognized in the ratio of phospholipids to nitrogen in the supernatant fraction.

One more problem to be investigated further is that we used the low vitamin diets in this investigation, therefore, the results may have been produced under the interaction of low protein and low vitamin contents. We intend to make clear this problem in the future.

Acknowledgement. We are grateful to Dr. Kiyoshi Ashida for the helpful advise in this experiment. 